\title{
Can sowing speed affect corn yield?
}

\author{
Aldir Carpes Marques Filho', Heitor Cardoso Ventura² \\ ${ }^{1}$ Universidade Estadual Paulista "Júlio de Mesquita Filho", Campus Botucatu, Botucatu, São Paulo, Brasil. E-mail: \\ aldir.marques@unesp.br
}

${ }^{2}$ Faculdades Integradas de Bauru, Bauru, São Paulo, Brasil. E-mail: heitor.cventura@ gmail.com

Received: 09/07/2021; Accepted: 15/09/2021.

\begin{abstract}
In sowing operation, it is es sential to control the factors that can affect the quality of seed and fertilizer deposition. These factors range from the correct choice of dosing mechanisms to machine regulation and operating speed control. The present research aimed to analyze the influence of sowing speed on the productive performance of the corn crop. The study was carried out at Fazenda São Geraldo, in the municipality of Boracéia, São Paulo. Four operating speeds 3, 5, 7 and $9 \mathrm{~km} \mathrm{~h}^{-1}$ were applied in a seeder, with a mechanical horizontal seed meter. The experimental design was carried out in strips. The results showed that sowing operational speed directly influences the final corn yield. There is a positive correlation between sowing speed and reduction in seedling emergence. The speed of $3.0 \mathrm{kmh}^{-1}$ showed the best results for seed deposition and yield. The speeds of 5,7 and $9 \mathrm{~km} \mathrm{~h}^{-1} \mathrm{presented}$ a reduction of $14.8,42.5$ and 67.2 bags per hectare.
\end{abstract}

Keywords: Zea Mays, Plantability, Sowing technology, Mechanization.

\section{A velocidade de semeadura pode afetar a produtividade do milho?}

\section{RESUMO}

Na operação de semeadura, torna-se fundamental o controle de fatores que podem prejudicar a qualidade de deposição de sementes e fertilizantes. Estes fatores vão desde a correta escolha dos mecanismos dosadores, até a regulagem da máquina e o controle da velocidade operacional. O presente trabalho teve por objetivo analisar a influência da velocidade de semeadura, no desempenho produtivo da cultura do milho. A pesquis a foi realizada na Fazenda São Geraldo, no município de Boracéia, São Paulo. Foram aplicadas quatro velocidades operacionais, sendo elas: 3, 5, 7 e $9 \mathrm{~km} \mathrm{~h}^{-1}$ em uma semeadora com dosador horizontal mecânico de sementes. O delineamento experimental foi realizado em faixas. Os resultados demonstraram que a velocidade operacional de semeadura influencia diretamente a produtividade final do milho. Ocorre correlação positiva entre a velocidade de semeadura e redução na emergência de plântulas. A velocidade de $3 \mathrm{kmh}^{-1}$ apresentou os melhores resultados de deposição de sementes e de produtividade para o equipamento avaliado. As velocidades de 5,7 e $9 \mathrm{~km} \mathrm{~h}^{-1}$, apresentaramredução de $14,8,42,5$ e 67,2 sacas por hectare, respectivamente.

Palavras-chave: Zea Mays, Plantabilidade, Tecnologia de semeadura, Mecanização. 


\section{Introduction}

Corn (Zea Mays) is regarded as one of the most important crops in the Brazilian agricultural scenario, this can be considered the second important crop, as soybean is usually planted in the first season crop. In Brazil, offseason corn was highlighted, as it has an area of 12 million sown hectares (IBGE, 2019). During the 2020/21 crop, the country had its productive area in the first crop season increased by $3.3 \%$ and in the second crop season by $8.1 \%$ (Conab, 2021).

The increase corn productivity depends on the application of modern production technologies and the correct adjustment in sowing machines and crop management. To achieve high levels of productivity, it is necessary to apply good practices for the implantation of crops (Marques Filho et al., 2020). Among the agricultural operations of importance for the corn cultivation, sowing represents the basis of formation and support for the beginning of the crop cycle (Alonço et al., 2015; Ferreira et al., 2019).

Proper seed deposition in the sowing row, with adequate spacing and depth is known as plantability (Bertelli et al., 2016). Plantability is important for the corn crop, as it determines the crop's productivity (Souza et al., 2019). In addition to sowing, speed and feeder models can affect corn productivity (Cortez et al., 2020). The corn crop is sensitive to the establishment of an adequate population, since it does not have the compensatory productive capacity in case of crop failures, a fact that occurs with the soybean crop.

In daily farming, it is common for machine operators to neglect the use of good practices, especially in regions where the ideal period for sowing is reduced. Therefore, they carry out the operation at high speeds, incurring in significant losses in the quality of seed deposition to the detriment of achieving high operating yields.

At high speeds, the seed and fertilizer dosing mechanism become overloaded and loses its ability to perform the function correctly. High speeds hinder crop establishment (Dias et al., 2009; Francisco et al., 2016; Correia et al., 2020). So, the poor initial formation of the crop can compromise its final productivity. Few researches evaluate productivity as a function of sowing speed.

Based on the reasons stated, this study aimed to evaluate the influence of operational speed in sowing, with a mechanical metering doser, on the final yield of the corn crop, specifically correlating productivity loss as a function of increased operational speed.

\section{Material and Methods}

The present study was carried out at Fazenda São Geraldo, in the municipality of Boracéia, state of São
Paulo, in crop year 2018, at latitude $22^{\circ} 07^{\prime} 24^{\prime} \mathrm{S}$, and longitude $48^{\circ} 46^{\prime} 02^{\prime \prime} \mathrm{W}$. The soil of the site was classified as red-yellow Latosol according to Santos et al. (2018) and as Typic Hapludox according to Soil Taxonomy (USDA, 2014). The soil preparation for the experimental area was carried out in a conventional way using a plow with 3 discs and a leveling harrow. The disc plow used was the Tatu $3 \times 26$ model, and the leveling harrow was Piccin with 32 discs. In the plowing operation, a machine pass was carried out, and for the leveling harrow two passes were carried out.

The experiment was implemented in an area 30 meters wide and 40 meters long, totaling 1200 square meters, intended for sowing corn. The seeds used belonged to the commercial hybrid SHS5560, with a purity of $99 \%$ and informed germination of $96 \%$. The experimental design was carried out in strips, containing four work strips, with thirty meters in length for each treatment, with an interval of 10 meters for speed stabilization and the treatments consisted of four sowing speeds, $\mathrm{V} 1=3, \mathrm{~V} 2=5, \mathrm{~V} 3=7$ and $\mathrm{V} 4=9 \mathrm{~km} \mathrm{~h}^{-1}$. It should be noted that for this doser model the recommended speed is $5 \mathrm{~km} \mathrm{~h}^{-1}$. In this research, speeds lower and higher than those recommended for the sowing machine were applied.

To carry out the experiment, a Jumil sowing-fertilizer machine model J2S was used, equipped with two sowing units, delimited by a spacing of $0.90 \mathrm{~m}$, which was regulated to deposit six seeds per meter (Figure 1). The agricultural tractor used was the Massey Fergusson - MF 4283, with traction type 4X2 TDA.

To adjust the speed of the tractor for seeding, the engine speed was stabilized at 1800rpm and the working gear that presented the desired speeds in each treatment was selected, then a spacing of fifty meters in length was delimited, and the operating speed was determined by equation 1 :

$$
\mathrm{V}=\frac{\mathrm{D}}{\mathrm{T}} \times 3,6
$$

Where:

$\mathrm{V}=$ velocity $\left(\mathrm{km} \mathrm{h}^{-1}\right)$;

$\mathrm{D}=$ Travelled distance $(\mathrm{m})$;

$\mathrm{T}=$ Travel time $(\mathrm{s})$;

After initial machine adjustment and speed selection, the sowing operation was started, with an initial speed of $3 \mathrm{~km} \mathrm{~h}^{-1}$, until completing six sowing lines, the same process was repeated for speeds of 5,7 and $9 \mathrm{~km} \mathrm{~h}^{-1}$. The central sowing lines were used for data collection, in plots of 6 meters in length with 10 repetitions in two central sowing lines. Simultaneously with the seeds in the sowing machine box, powdered graphite was applied at the rate of 4 grams of graphite for each $\mathrm{kg}$ of seeds. 

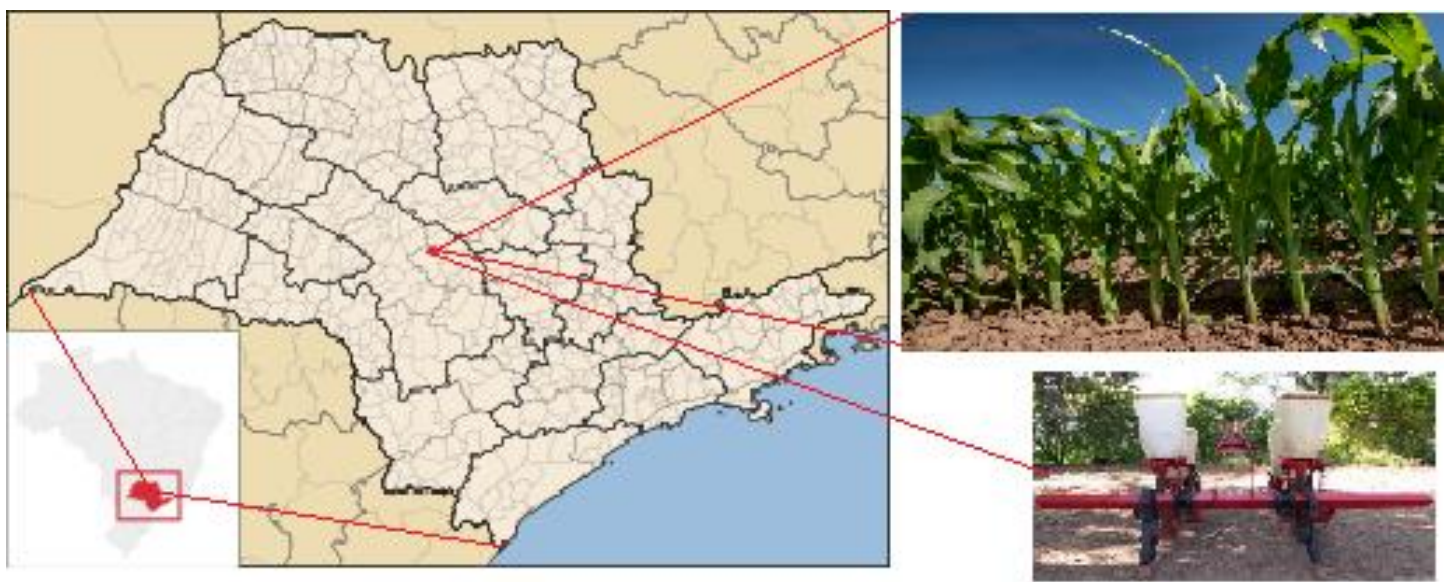

Figure 1. Experimental location and two-row fertilizer seeder, equipped with mechanical doser of seed and fertilizer

Seven days after sowing, emergency data collection was started, where the number of viable seedlings in each treatment was evaluated. Collections were carried out at 7, 23 and 37 days after sowing (DAS). The results obtained were compiled via Microsoft Excel spreadsheet, where Pearson's linear correlation tests were applied, and the emergence regression coefficients were demonstrated as a function of different operational speeds.

At 120 DAS, the evaluation of the influence of treatments on the final productivity of the crop began. Harvesting was carried out manually and started when the corn cobs were in the natural senescence phase. The cobs that were part of each treatment were identified and separated after harvesting, where the threshing was carried out to evaluate the productivity of the plots.

The total grain mass of each treatment was evaluated with the aid of a precision analytical balance and extrapolated to productivity in bags per hectare. The results were submitted to the Anderson-Darling normality test and analysis of variance, followed when necessary, by Tukey's mean comparison test at $95 \%$ probability. All analyzes were performed using Minitab v.16 statistical software.

\section{Results and Discussion}

Results showed that emergence has high correlation between sowing speed and crop establishment, it was found that with the increase in speed there was a reduction in the number of effectively emerged seeds. Figure 2 describes the behavior of the straight line that intersects the sampled points, where it is possible to detect the linearity between increase in speed and quantity of emergency plants. Thus, the speed reduction allowed the seed feeder to perform the sowing task with better quality, a fact that is highlighted by the higher emergence rates at low speeds. The lower speeds allow the dosing mechanism to work with less overload.

The results obtained in this study collaborate with those obtained by Dias et al. (2009), who in an experiment evaluating seed distribution under different operating speeds in maize crops, highlighted that higher displacement speeds negatively affect seed distribution and cause higher percentages of faulty and multiple spacing. Bottega et al. (2017), in a study with corn sowing in the same type of soil as used in this research, found that the increase in speed caused an increase in the incidence of faulty and double spacing, regardless of the seed meter used. The data presented by the authors collaborate with those obtained in this research.

The $\mathrm{r}^{2}$ of 0.84 for the relationship between emergence and operational speeds shows that the displacement speed directly affects the establishment of the crop, reducing the total final stand. Higher displacement speeds reduce the establishment of seedlings because they lead to greater unevennes $s$ in the deposition in depth in the seed furrow. Another negative factor is the high peripheral speed of the seed metering disk, which causes damage to the seeds, reducing germination and emergence capacity.

Cortez et al. 2020 found similar results for the increase in speed in relation to seeding quality, however the authors stated that pneumatic type feeders allow seeding at higher speeds without losing quality. It appears that the emergence of plants at $7 \mathrm{~km} \mathrm{~h}^{-1}$ and $9 \mathrm{~km}$ $\mathrm{h}^{-1}$ did not differ statistically, possibly because the work limit of the feeder has been reached. Mechanical seed dosers, in older seeder models, present limitations in the individualization and deposition of seeds in the soil.

Bertelli et al. (2016) found a direct relationship between increased sowing speed and faulty spacing for the soybean crop. The authors claim that increasing speed reduces sowing uniformity. The results of the analysis of variance and means tests for seedling emergence at each depth are described in Table 1.

The speed variations showed statistically significant differences between treatments V1, V2 and V3 or V4, with the best result for germination and crop establishment occurred at the speed of $3 \mathrm{~km} \mathrm{~h}^{-1}$, followed by the speed of $5 \mathrm{~km} \mathrm{~h}^{-1}$ with difference between them. 


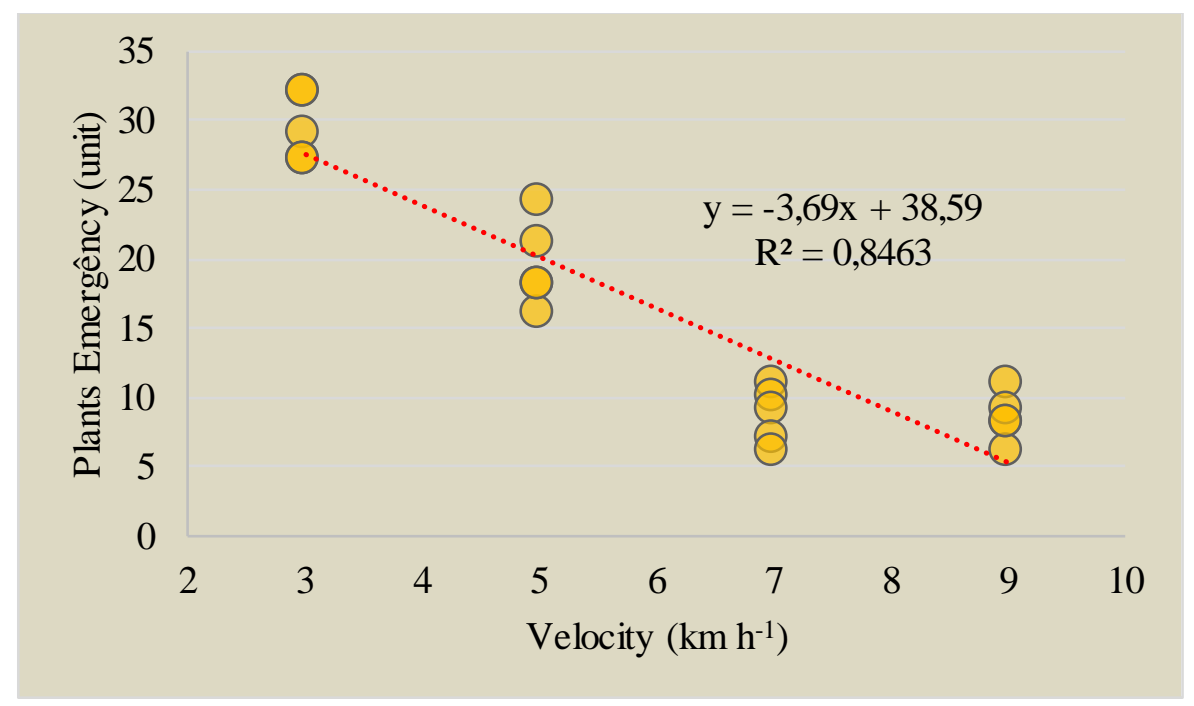

Figure 2. Pearson linear correlation between seedling emergence and sowing speeds $3,5,7$ and $9 \mathrm{~km} \mathrm{~h}^{-1}$

Table 1. Tukey test results at $95 \%$ probability for the variables operating speed and mean emergence at 7,23 and 37 days after sowing (DAS).

\begin{tabular}{clllll}
\hline \multirow{2}{*}{ Treatment } & $\begin{array}{l}\text { CV } \\
(\%)\end{array}$ & $\mathrm{n}$ & $\begin{array}{c}7 \\
\text { DAS }\end{array}$ & $\begin{array}{c}23 \\
\text { DAS }\end{array}$ & $\begin{array}{c}37 \\
\text { DAS }\end{array}$ \\
\hline $\mathrm{V} 1$ & 12.21 & 10 & $14.6 \mathrm{a}$ & $14.7 \mathrm{a}$ & $15.2 \mathrm{a}$ \\
\hline $\mathrm{V} 2$ & 20.19 & 10 & $10.2 \mathrm{~b}$ & $10.7 \mathrm{~b}$ & $10.7 \mathrm{~b}$ \\
\hline $\mathrm{V} 3$ & 24.01 & 10 & $6.1 \mathrm{c}$ & $6.3 \mathrm{c}$ & $6.9 \mathrm{c}$ \\
\hline $\mathrm{V} 4$ & 31.12 & 10 & $4.9 \mathrm{c}$ & $4.9 \mathrm{c}$ & $5.1 \mathrm{c}$
\end{tabular}

*In the column means with equal letters do not differ from each other by the $5 \%$ tukey test.

At the speeds V3 $\left(7 \mathrm{~km} \mathrm{~h}^{-1}\right)$ and V4 $\left(9 \mathrm{~km} \mathrm{~h}^{-1}\right)$ there was no statistical difference, which can be explained by the limitation of the sowing machine in performing the operation above the speed limits pre-established in the equipment manual. Correia et al. (2020) stated that the operating speed is directly related to the seeding quality, so that higher speeds increase the faulty and double spacings and reduce the acceptable spacings.

The results show that with the increase in speed, failures in seed deposition were generated, so that when reaching higher speeds, the seeder loses the ability to follow the irregularities of the terrain, thus causing some seeds to be deposited deeply and others superficially, which certainly affected the percentage of emergence in a negative way. These results corroborate those obtained by Bottega et al. (2014). According to Volk and Cogo (2014), traditional tillage operations, with the use of plows and harrows generally increase the total porosity and availability of water for the roots but cause some problems such as greater susceptibility to erosion, leading to soil losses and water by weathering agents.

After manual harvesting of corn at 120 DAS, it was possible to observe the effect of velocities on the conformation of corn cobs. The higher speeds provided larger cobs, due to the greater number of failures in the crop and uneven sowing (Figure 3).
The larger sizes found on the cobs at V3 and V4 speeds did not translate into greater overall productivity. The gain in mass and size compared with the lower speed treatments, does not become economically and operationally viable, because in treatments 3 and 4 where the corn cobs were larger, a smaller number of cobs per plot was obtained. However, in V1 and V2 there were corn cobs of reduced sizes but in larger amounts of cobs per plot.

The set of data obtained shows that the weight of the total grains harvested from each plot per treatment presented a statistically significant difference. Thus, with a speed of $3 \mathrm{~km} \mathrm{~h}^{-1}$ the best seed deposition was obtained, but with the lowest operational yield. Ferreira et al. (2019) obtained similar results, and the speed with the best seed deposition was $3.5 \mathrm{~km} \mathrm{~h}^{-1}$.

The sowing speed at $5 \mathrm{~km} \mathrm{~h}^{-1}$ presents a positive relationship between sowing quality and operational yield, a fact that corroborates those obtained by Cortezet al. (2020), where the authors obtained the best performance at $5 \mathrm{~km} \mathrm{~h}^{-1}$ in mechanical doser. Treatments 3 and 4 can be considered the ones with the highest operational efficiencies, however they had a greater negative influence on deposition. The fluidity of the seeds in the feeder is affected by the operating speed. Chemical seed treatment can also interfere with sowing quality and affect seed slip in the feeder (Pereira et al. 2021b).

For a speed increase of $2 \mathrm{~km} \mathrm{~h}^{-1}, 11.7 \%$ is lost in grain yield. In other words, by choosing the speed of $5 \mathrm{~km} \mathrm{~h}^{-1}$ over the speed of $3 \mathrm{~km} \mathrm{~h}^{-1}$, the producer fails to earn 14.8 grain bags. If chosen $7 \mathrm{~km} \mathrm{~h}^{-1}$ or $9 \mathrm{~km} \mathrm{~h}^{-1}$ in relation to 3 $\mathrm{km} \mathrm{h}^{-1}$, would be lost $35.1 \%$ (42.5 bags) and 54.75\% (67.2 bags) respectively. Seeding is a high-risk operation, and many factors influence the quality of the process. Pereira et al. (2021) found differences in seed distribution depending on the format of commercial hybrids of maize. 


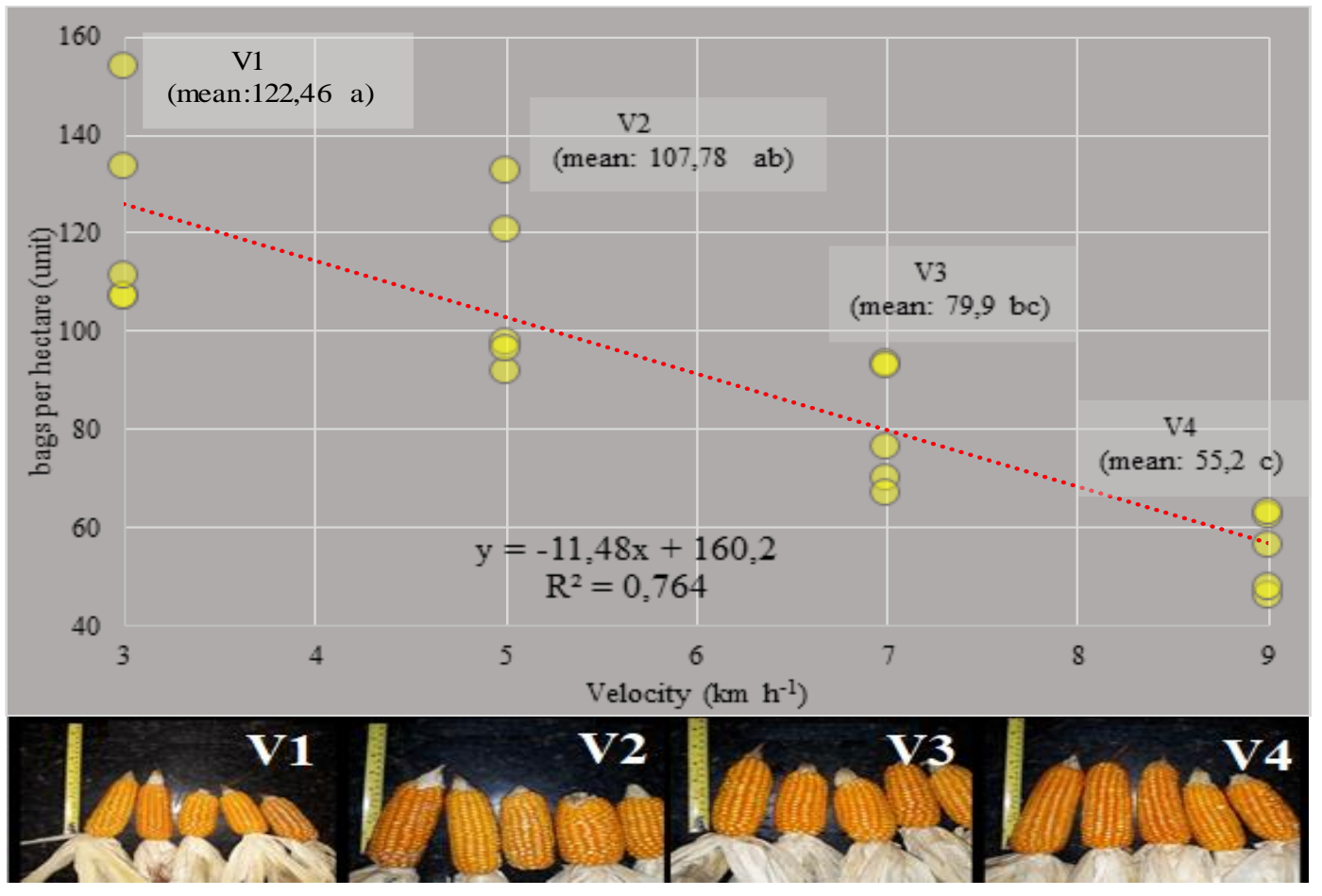

Figure 3. Corn cob size and formation (below) and Pearson's linear correlation for speed as a function of yield in each treatment $(*$ means with equal letters do not differ by the 95\% tukey test. Coefficient of Variation of V1; V2; V3 and V4: 16.93; 15.71; 15.86; 12.02 , respectively)

Seeds with rounded shapes presented better performance in pneumatic feeders. In this research, the shape of seeds was not evaluated, however, this variable needs to be better investigated due to different sowing speeds. Souza et al. (2019) found decreasing relationships of seed deposition uniformity between velocities 7.2 and $8.6 \mathrm{~km} \mathrm{~h}^{-1}$. The authors also noted that furrower depth affects seed deposition. High sowing speed reduces the number of viable plants, which negatively compromises the final crop yield.

Results of this study showed that sowing operation is fundamental for success of the agricultural enterprise and its speed control is related to the quality of seed deposition in the soil and the final productivity of the corn crop. Producers or farmers able to carry out this operation at low speeds will achieve better results. When planting corn in the second crop, it is common that the farmer does not have time to carry out this operation at low operating speeds, since, in some productive regions of Brazil, the limiting factor is the soil moisture at the time of sowing. In many cases there is a lack of machines to finish the job within the ideal time, this research has shown that farmers who work at high-speed seeding, collect losses in the crop.

\section{Conclusions}

The higher operational speeds of mechanized sowing, affected the deposition of seeds and the formation of an adequate corn stand, reducing the final yield.
There is a positive correlation between sowing speed and reduction in seedling emergence. At the highest operating speeds, the lowest seeding qualities are obtained.

The speed $3.0 \mathrm{kmh}^{-1}$ showed the best results forseed deposition and yield. The speeds 5,7 and $9 \mathrm{~km} \mathrm{~h}^{-1}$ presented a reduction of $14.8,42.5$ and 67.2 bags per hectare, respectively.

\section{Authors' Contribution}

Aldir Carpes Marques Filho contributed to writing, revising, statistical analysis, and interpretation of results. Heitor Cardoso Ventura contributed to the setup of experiment, data collection and writing.

\section{Bibliographic References}

Alonço, A.S., Silveira, H.A.T., Cardinal, K.M., Rist, G.P., 2015. Distribuição de sementes de algodão e girassol em diferentes velocidades e inclinações em dosadores pneumáticos. Scientia Agraria, 16(2), 63-70.

Bottega, E.L., Vian, T., Guerra, N., Oliveira Neto, A.M., 2017. Diferentes dosadores de sementes e velocidades de deslocamento na semeadura do milho em plantio direto. Pesquisa Agropecuária Pernambucana, 22(v.u.), 13-22. DOI: https://doi.org/10.12661/pap.2017.014

Bottega, E.L., Rosolem, D.H., Oliveira Neto, A.M., Piazzetta, H.V.L., Guerra, N., 2014. Qualidade da semeadura do milho em função do sistema dosador de sementes e velocidades de 
operação. Global Science and Technology, 7(1), 107-114. DOI: https://doi.org/10.12661/gst.2014.365

Bertelli, G.A., Jadoski, S.O., Rampim, L., Maggi, M.F., 2016. Desempenho da plantabilidade de semeadoras pneumática na implantação da cultura da soja no cerrado piauiense-Brasil. Revista Brasileira de Tecnologia Aplicada nas Ciências Agrárias, 9(1), 11-19. DOI: https://doi.org/10.5935/PAeT.V9.N1.10

CONAB. COMPANHIA NACIONAL DE ABASTECIMENTO. Acompanhamento da safra brasileira de grãos, 2021. Brasília, 8(10), 1-66. www.conab.org.br (acessado 09 de julho de 2021).

Correia, T.P.S., Lopes, A.G.C., Faggion, F., Silva, P.R.A., Sousa, S.F.G., 2020. Semeadura de soja em função de mecanismos dosadores e velocidade operacional. Energia na Agricultura, 35(2), 190-198. DOI: https://doi.org/10.17224/EnergA gric.2020v35n2p 190-198

Cortez, J.W., Anghinoni, M., Arcoverde, S.N. 2020. Seed metering mechanisms and tractor-seeder forward speed on corn agronomic components. Engenharia Agrícola, 40 (1), 61-68. DOI: https://doi.org/10.1590/1809-4430-Eng.Agric.v40n1p61$68 / 2020$

Dias, V.O., Alonco, A.S., Baumhardt, U.B., Bonotto, G. J., 2009. Distribuição de sementes de milho e soja em função da velocidade e densidade de semeadura. Ciência Rural, 39(6), 1721-1728. DOI: https://doi.org/10.1590/S010384782009005000105

Ferreira, F.M., Oss, L.L., Almeida Carneiro, M., Litter, F.A., 2019. Distribuição longitudinal na semeadura do milho com semeadoras de precisão mecânica e pneumática. Nativa, 7(3), 296-300. DOI: http://dx.doi.org/10.31413/nativa.v7i3.7553

Francisco, R.E., Machado, T.M., Taubinger, L., Quadros, D., 2016. Influência da velocidade de deslocamento na distribuição de sementes e produtividade de soja. Revista Engenharia na Agricultura, 24(1), 63-67. DOI: https://doi.org/10.13083/reveng.v24i1.634
IBGE. INSTITUTO BRASILEIRO DE GEOGRAFIA E ESTATÍSTICA, 2019. Levantamento Sistemático da Produção Agrícola. https://sidra.ibge.gov.br/tabela/839. (acessado 25 de julho de 2021.

Marques Filho, A.C., Rusconi, L.H., Silva, P.R.A., 2020. Plantabilidade e distribuição longitudinal de sementes de algodão com diferentes conjuntos disco-anel em dosador mecânico. Energia na agricultura, 35(4), 476-483. DOI: https://doi.org/10.17224/EnergAgric.2020v35n4p476-483

Pereira, J.C.S., Marques Filho, A.C., Grudtner, G.H., Silva, P.R.A., 2021. O formato das sementes pode influenciar a plantabilidade do milho em dosadores pneumáticos? Energia na agricultura, 36(1), 17-27. DOI: http://dx.doi.org/10.17224/EnergA gric.2021v36n1p 17-27

Pereira, J.C.S., Marques Filho, A.C., Souza, F.L.P., Silva, P.R.A., 2021b. Plantability and influence of the application of graphite associated with the chemical treatment of soybean seeds. Revista de Agricultura Neotropical, 8(3), 5997. DOI: https://doi.org/10.32404/rean.v8i3.5997

Santos, H.G., Jacomine, P.K.T., Anjos, L.H.C., Oliveira, V.A., Lumbreras, J.F., Coelho, M.R., Cunha, T.J.F., 2018. Sistema brasileiro de classificação de solos, $6^{\circ}$ ed., Brasília. http://www.infoteca.cnptia.embrapa.br/infoteca/handle/doc/10 94003

Souza, C.M.A., Rafull, L.Z.L., Arcoverde, S.N.S., Bottega, E.L., Orlando, R.C., 2019. Desempenho de semeadora-adubadora de milho de segunda safra em semeadura direta. Agrarian, 12(45), 346-353. DOI: https://doi.org/10.30612/agrarian.v12i45.7965

USDA, UNITED STATES DEPARTMENT OF AGRICULTURE 2014. Soil Survey Staff, Keys to Soil Taxonomy, $12^{\text {th }}$ ed, Washington.

Volk, L.S.; Cogo, N.P., 2014. Erosão hídrica, em três momentos da cultura do milho, influenciada por métodos de preparo do solo e semeadura. Revista Brasileira de Ciência do Solo, 38(2), 565-574. 